\title{
Shakespeare's poetry in action: between thought and passion
}

La poésie de Shakespeare en action : entre pensée et passion

\section{Alessandro Serpieri}

\section{(2) OpenEdition}

1 Journals

\section{Electronic version}

URL: http://journals.openedition.org/shakespeare/1051

DOI: 10.4000/shakespeare.1051

ISSN: 2271-6424

\section{Publisher}

Société Française Shakespeare

\section{Printed version}

Date of publication: 1 November 2007

Number of pages: 165-182

ISBN: 2-9521475-3-1

\section{Electronic reference}

Alessandro Serpieri, «Shakespeare's poetry in action: between thought and passion », Actes des

congrès de la Société française Shakespeare [Online], 24 | 2007, Online since 30 March 2010, connection on 19 April 2019. URL : http://journals.openedition.org/shakespeare/1051 ; DOI : 10.4000/

shakespeare. 1051

This text was automatically generated on 19 April 2019.

(c) SFS 


\title{
Shakespeare's poetry in action: between thought and passion
}

\author{
La poésie de Shakespeare en action : entre pensée et passion
}

\author{
Alessandro Serpieri
}

1 Drawing from my experience both as a critic and as a translator, I will investigate some of Shakespeare's distinctive ways of creating poetry in action: that is, poetry that develops on stage - and therefore is endowed with a performative power - and poetry that grows out of a dialectics between passion and thought. Whether the text is a play or a narrative poem, or a sonnet - though in the latter cases by using different modes of expression -, Shakespeare's poetry always conveys the process of minds "in situation". As Coleridge brilliantly noted, Shakespeare goes on evolving a line of thought and passion out of, or in combination with, at least another one:

In Shakspeare one sentence begets the next naturally; the meaning is all interwoven. He goes on kindling like a meteor through the dark atmosphere [...] Shakspeare's intellectual action is wholly unlike that of Ben Jonson or Beaumont and Fletcher. The latter see the totality of a sentence or passage, and then project it entire. Shakspeare goes on creating, and evolving B. out of A., and C. out of B., and so on, just as a serpent moves, which makes a fulcrum of its own body, and seems for ever twisting and untwisting its own strength. ${ }^{1}$ (my italics)

In his many lectures on Shakespeare, as well as in his reported notes, while accounting for the overall meaning and structure of his plays, Coleridge devoted the subtlest analyses to his dramatic language. In the quoted passage, he summarizes in two pregnant images his critical discourse on Shakespeare's ingeniousness as one which begets new expressions from previous expressions and intertwines them in co-occurring semantic and/or figurative isotopies. ${ }^{2}$ It is an imagination in action in that it does not follow a linear progression of meaning, but rather develops according to a serpentine, dynamic movement that produces sense both expanding the previous one and contracting it in order to release new unexpected sense. The dramatic discourse unfolds itself according to the circumstantial standpoints of characters who, at the same time, think, feel and act. The lyrical discourse, on the other hand, is that of a voice which creates its own dramatic 
movement and does so in relation to other persons or entities involved in either specific or universal situations.

Such a mobile, restless, and inventive, imagination often forces language to new modes of expression, in terms both of neologisms and of original syntactical constructs, and thus provides an endless hermeneutic challenge for critics and translators.

I can consider here only a few examples of Shakespeare's poetry in action, and I will group them into three main categories:

1. a character's gradual discovery of his own thoughts and passions in the process of speech (the examples will be taken from Macbeth and The Winter's Tale);

2. a character's transmission of his thoughts and passions to another character (the passages I will refer to are from Iago's temptation of Othello);

3. the poet, or the voice of the enunciation, gradually discovering his own thoughts and passions (a few sonnets will thereby be discussed).

8 In all these categories the discourse relies on an essentially dialogic procedure, which is internalized in the mind of one character in 1. and 3., albeit from different standpoints since it is indirectly addressed to different receivers (respectively, the audience in the theatre, and the reader on the page); in 2., on the contrary, it develops the stage action concerning the (il-)locutionary acts of two or more characters.

1. Interpreting, and translating, Shakespeare is always a very hard task, but it is all the more so in some plays, particularly the later ones, where elocution may verge on an apparent implosion of meaning. In such cases the characters' discourse proves extremely tortuous, semantically ambiguous, intricate and fragmented to the point of sounding almost inaccessible. In the later plays, as Frank Kermode has noted, illocution expresses "a turbulent thinking, so different from plainly formulated thought, set out clearly and reinforced by elaborately illustrative and copious comparisons"3. This kind of illocution is functional to "the representation of excited, anxious thought; the weighing of confused possibilities and dubious motives; the proposing of a theory or explanation followed at once by its abandonment or qualification, as in the meditation of a person under stress to whom all that he is considering can be a prelude to vital choices, emotional and political" 4

10 In the same regard, Keir Elam has coined the definition of a rhetoric of inelocutio with reference to Macbeth and other later plays, when

the whole system of elocution suddenly implodes or self-destructs in advocating modes of discursive disintegration, fragmentation, hesitation, reticence, compression and opacity. The simulacrum, or simulatio, of the struggling speaker about to lose control of his own discourse, and perhaps of his thought processes, under the pressure of passion, is perhaps the highest achievement to which the rhetoric of pathos through ethos can aspire, since there is nothing so delicate and so difficult to get away with as an artfully constructed artlessness. ${ }^{5}$

11 Shakespeare's elocution, when entrusted - in Kermode's words - with "elaborately illustrative and copious comparisons", may develop its meaning and its rhetoric in a sinuous, and yet transparent, way. This can be seen, for instance, in Bassanio's speech to Portia (The Merchant of Venice, III.ii.88-101), when he is about to make his choice of the right casket and is brought to use a complimentary ornamental discourse by which he wants to exhibit his distrust of shows and to capture the approval of the lady: 


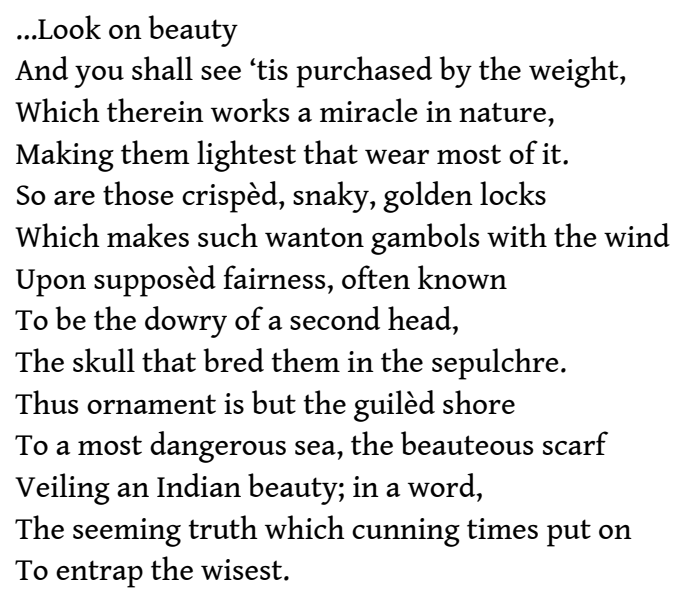

On other occasions, elocution can be artfully opaque and almost inaccessible, its purpose being that of exposing a character's personality and style. Let's take just one example, from Hamlet, I.iii.126-31, where Polonius dissuades Ophelia from continuing her relationship with the prince:

Do not believe his vows; for they are brokers

Not of that dye which their investments show,

But mere implorators of unholy suits,

Breathing like sanctified and pious bawds

The better to beguile.

In his typically obscure and tortuous syntax and semantics, Polonius here conveys several lines of meaning which can hardly be grasped in full by Ophelia and by the audience. The pluriisotopy of these lines springs from the initial brokers, which, as has been noted by Nigel Alexander,

may be of three kinds and Polonius unites all three functions in this complex series of images: a) dealers in finance who are not of the true colour or appearance (dye) which their authorising documents (investments) indicate but simply solicitors for improper requests who talk as if their proposals were holy and religious in order to deceive their victims; b) go-betweens in matters of love who are not of the kind of men claimed by the garments they have borrowed (from the church) but simply makers of lewd and immoral suggestions who talk the language of marriage vows in order to deceive their victims, c) dealers in old clothes - though this meaning is less fully worked out.

Alexander thus concludes: "Hamlet is thus a shady financier, a pander who promises marriage, and an old clothes man."' Three isotopies, developing from three different agents, continually overlap, so that all key words sound equivocal, open to more than one meaning. The ambiguous image of Hamlet as false wooer of Ophelia springs especially from Polonius' ingenious use of the following terms: investments (at the same time, financial documents, garments of go-betweens, second-hand clothes), implorators (solicitors and entreaters), unholy suits (prophane procedures and improper mediations), bonds (contractual obligations and marriage vows and warranties). It is a difficult passage to understand and to translate, but it does not contain any urgent emotion at work.

Quite different is the case of elocution expressing a problematic thinking through passion. This is apparent especially in the later plays, where elocution repeatedly verges on inelocution, due to the anxiety of the speaker, whose interior discourse disbands rather than flowing, compresses its meanings, breaks up, and often forces language to new modes of expression. Here Shakespeare's dramatic poetry resides in disturbed inner 
dialogues, in which a character gropes for a response to a vital question. Due to lack of space, I can only hint at just a couple of passages from Macbeth and from The Winter's Tale, where the main character's passion is at its pitch.

At the beginning of the seventh scene of the first Act, Macbeth copes with an ontological question:

If it were done when 'tis done, then 'twere well

It were done quickly. If th'assassination

Could trammel up the consequence, and catch

With his surcease success; that but this blow

Might be the be-all and the end-all, here,

But here upon this bank and shoal of time,

We'd jump the life to come...

17 His convulsive meditation turns on doing and being, that is to say on the ontological question of the effectiveness of acting in time in order to achieve being in time. In his frantic reasoning, Macbeth shows how keenly aware he is of the set-back that lies at the basis of his, and his wife's, intention to achieve power and be the power by violating, through the murder of the sacred king, the very symbolic framework which grants being. The extreme difficulty of his choice is expressed by the inextricable knot of temporal planes - the future (If it were done) after the future of the imminent proposed regicide ( when 'tis done), and the hypothetical present of that decision (then 'twere well) - and is confirmed by the following suspended hypothesis, "If th'assassination / Could trammel up the consequence," where the new verbal phrase trammel up is produced in order to signify the impossible target at which Macbeth is aiming. A target which, again, finds its formula in two other neologisms: "the be-all and the end-all." Macbeth's vexation - here, before the action, and then throughout the play as an outcome of the inconsequentiality of his action - is that of not being able to push doing to the point of achieving being: being king for all his life, past the risk of the indefinite becoming (that is acting). ${ }^{7}$ It is not by chance that, once king, he will feel compelled by his fear to act endlessly and ruthfully as if he wanted to annul or to anticipate any future time, while his previously determined wife leaves the stage up to the moment of her nocturnal delirium. ${ }^{8}$

Macbeth's soliloquy goes on recalling the "double trust" which should protect Duncan, since he is both his kinsman and his subject. At this point, several images are deployed and overlapped in convulsive lines:

...Besides, this Duncan

Hath borne his faculties so meek, hath been

So clear in his great office, that his virtues

Will plead like angels, trumpet-tongued against

The deep damnation of his taking-off,

And Pity, like a naked new-born babe,

Striding the blast, or heaven's cherubin, horsed

Upon the sightless couriers of the air,

Shall blow the horrid deed in every eye,

That tears shall drown the wind.(1l.16-25)

19 Now his language has become mostly pictorial. It presents a baroque scenario: angels blow trumps as in a last day judgement; Pity, personified like the innocent putto typical of many contemporary paintings and sculptures, rides the blast (possibly, both in the auditory sense of 'call' of a trump, and in the visual sense of wind - often represented iconographically like a human being ${ }^{9}$ - ejected by the trumps blown by the angels); Pity is then followed or substituted by the image of a cherubin horsed on the same blast. Thus 
we have a dynamic, and at the same time tortuous, sequence: virtues, visualized like angels, introduce Pity, putto, and cherubin, who in their turn blow, announce, propagate the regicide, "the horrid deed" about to be done, and thus provoke a universal cry which "shall drown the wind". The reader's or spectator's response to the entire soliloquy which opens on very obscure lines due to the interweaving of different layers of meaning, and closes with an explosion of overlapping images - may be best summarized by William Empson's statement: "The meanings cannot all be remembered at once, however often you read it; it remains the incantation of a murderer, dishevelled and fumbling among the powers of darkness." 10

I will now turn, albeit briefly, to Leontes' suddenly conceived jealousy in The Winter's Tale, I.ii. Let us consider 11.136-144, a passage which many critics have regarded as possibly the most difficult crux in the canon. In fact, Leontes' elocution is extraordinarily compressed, and elliptical to the point of allowing quite different emendations and interpretations. I cannot discuss here all the alternative readings which have been proposed since Rowe's edition. In my opinion, however, the Folio reading is substantially correct:

... Can thy Dam, may't be

Affection? Thy Intention stabs the Center,

Thou do'st make possible things not so held,

Communicat'st with dreams (how can this be?)

With what's unreall: thou coactive art,

And fellow'st nothing. Then 'tis very credent,

Thou may'st co-joine with something, and thou do'st,

(And that beyond Commission) and I find it,

(And that to the infection of my Braines,

And hardning of my Browes.)

Pope and Johnson followed Rowe in breaking down the enjambement between the first and the second lines and in substituting Affection with Imagination, and the question mark with the exclamation mark. The meaning is thus somehow clarified, but also belittled. An editorial and critical line (Steevens, Malone, etc.) reads Affection as meaning imagination, even though it rejects Rowe's emendation. Another critical line, which goes from Capell to Kermode, reads Affection as the passion of jealousy which is beginning to shake Leontes. Still another line, more faithful to the punctuation of the Folio, refers Affection to Hermione (thy dam) and interprets it as "lust", according to the meaning specified in OED 3. The next puzzle is constituted by the following Thy intention: Stephen Orgel points out that 'the referent of 'thy intention' is unclear, and upon this depends the meaning of the remainder of the speech," ${ }^{11}$ Jean Howard, instead, opts for Leontes' jealousy: "Passion (probably the passion of jealousy), your intensity (intention) pierces my heart or to the core of my being." ${ }^{12}$

To sum it up, is Leontes referring to Hermione's passion (love and lust) or to his passion (jealousy)? The Folio's reading is not that ambiguous: it is Hermione's affection. But can one be sure that affection here means passion or even lust? At the beginning of the narrative source of the play, Greene's Pandosto, we find both affected and affection referred to Bellaria-Hermione, and qualified as a lawful and innocent feeling. It is a feeling, though, which the narrator ambiguously brings the reader to suspect as concealing something more than affection in her relationship with Egistus-Polixenes. ${ }^{13}$ If we accept the Folio's reading, we should imagine that Leontes, soon after mentioning Affection in the sense of friendly feeling, shifts to the other meaning of passion or lust. This shifting may be seen in his immediate addressing himself about its dubious significance: "Thy intention 
...", another complex word, meaning both aiming at something, like in the Latin intendere (to tend to, to aim at), and intensity. Leontes, therefore, seems to be upset both by the recipient, his friend Polixenes, to whom Hermione is addressing her affection, and by the apparent intensity of its manifestation.

In the following lines, Hermione's passion is seen by him as limitless because it springs from the deepest layers of her mind. It was there even before finding the recipient on whom it now discharges itself; it lay in her dreams, in what is unreal. If her passion has always been there, hidden in her most secret fantasies, it can very well co-joine (another hapax) with something real - Polixenes at the moment - and thus being coactive, once it has found its target, it knows no limits: it goes beyond Commission, another strange word in the context, which seems to mean beyond any lawful authorization of her conscience.

In a few lines of great dramatic intensity, Affection has undergone a radical change, losing all shade of friendship and turning into passion, which is her imaginary desire hidden in her breast even before investing itself into a real lover. She is intrinsically unfaithful and her affection amounts to the infection of Leontes' brain, now working within the imaginary space of frenzied jealousy. Leontes' elocution-inelocution is that of a speech in the making, still groping for its own meaning. ${ }^{14}$

2. Jealousy is the realm of the imaginaire. An endogenous obsessive feeling in Leontes, in Othello it is whipped up by Iago into the mind of the Moor. Thus, while Leontes' inelocution springs from his interior monologue-dialogue which forces language to ellipses, equivocal expressions, and neologistic or rare linguistic tracks, in Othello other tricks of language convey an elocution-inelocution by which the imaginary betrayal is gradually transmitted by Iago to his victim. The great scenes of his temptation are a triumph of indirectness over directness, of simulacra over signs, of the imaginaire over the real. As is well known, his weapons are those of reticence, litotes, negation, hypothesis, equivoque, and suspension. He says things while pretending that he is not saying anything. By denying or delaying his own saying, he aims at making Othello think on and elaborate Desdemona's betrayal. Pretty early in the first long scene (III.iii), Othello begs him to show his thought and soon afterwards to speak it out:

I prithee speak to me as to thy thinkings,

As thou dost ruminate, and give thy worst of thoughts

The worst of words. (III.iii.134-36)

Iago's reply is a masterpiece of rhetoric, in which he conveys a puritan representation of anybody's possibly vile psychic depths. Anybody includes himself, but at the same time, through an indirect suggestion, hints at Desdemona, whose pure breast may not be what it claims to be:

Good my lord, pardon me;

Though I am bound to every act of duty

I am not bound to that all slaves are free to -

Utter my thoughts? Why, say they are vile and false?

As where's that palace whereinto foul things

Sometimes intrude not? Who has a breast so pure

But some uncleanly apprehensions

Keep leets and law-days and in session sit

With meditations lawful? (III.iii.136-44: my italics)

He starts by addressing the Moor as a slave would his master, a relationship he is about to invert, as Othello's use of the same verb of submission proves in 1.217: "I am bound to thee for ever." Then he unfolds the pregnant image of foul things intruding even upon a 
sumptuous palace. The verb to intrude suggests the creeping of repellent animals into cellars or dungeons. A second, court of law, image follows to show the inner trial which takes place in any breast, even the supposedly pure, when the unclean apprehension clashes with the lawful meditation. He is impudently drawing a faithful self-portrait, as of a person hiding unavowable sins, a portrait which, in his next speech, he soon qualifies as that of a person whose excessive zeal goes haunting human vices even where they are not: "As I confess it is my nature's plague / To spy into abuses, and oft my jealousy / Shapes faults that are not" (1l.149-51). Why is he taking the risk of exposing himself? His intention is clearly that of putting the stress on foul, unclean, and abuse, the words for the vices of which Desdemona must be found guilty, and to name for the first time in a displaced sense (that of zeal, the puritan attitude that denounced any kind of abuse) the key word jealousy, which Othello is called to elaborate on.

To do so Othello must be left alone for a moment. And this is what Iago soon arranges. He pretends to go away and thus leaves the Moor to think on his own. Othello starts by reassuring himself of the honesty of Iago ("This fellow's of exceeding honesty..."); then he decides that, if Desdemona is false to him, he will let her fly away like a haggard (the first animalesque image of Iago's repertoire to invade his mind); he further regrets his being black, uncultivated and old, and curses the institution of marriage which does not ensure faithfulness because the appetites of women may always draw them to others: "O $\mathrm{Curse}$ of marriage / That we can call these delicate creatures ours / And not their appetites!" A key-word of Iago's imagination, the female appetite, has infected his mind. And to the same effect other images worked out by Iago have contributed, as can be seen in the following lines:

... I had rather be a toad

And live upon the vapour of a dungeon

Than keep a corner in the thing I love

For others' uses. (11.274-77)

The repellent animal in a dungeon - a place which appears to be a metaphor for what is secret and hidden - echoes Iago's words at 11.140-44 ("As where's that palace whereinto foul things / Sometimes intrude not?"): toad visualizes foul things, while dungeon identifies the plausibly subterranean hidden place alluded to by Iago. To be explicit, what is hidden is sex, and more precisely the vagina ("the thing I love"), in which Othello now refuses the very idea of keeping a corner: a corner in the poky space now allowed to him in her otherwise bounteous sex open to many. ${ }^{15} \mathrm{His}$ mind is upset and his new vulgar language brings him to the very place where betrayal is supposed to happen.

To that place he will obsessively return later in the play, when he accuses Desdemona in IV.ii.58-63:

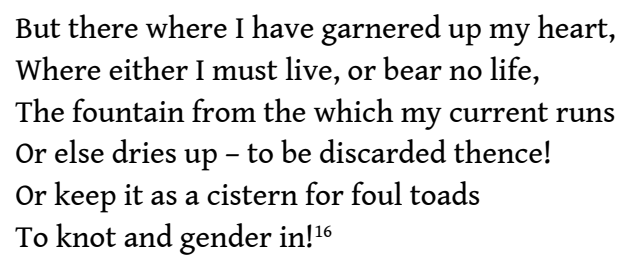

The beneficial stream of his life, which flew from Desdemona, has come to a stop since he has been excluded from it. That "fountain" has been degraded by her betrayal to still water in a cistern (which echoes the dungeon of his previous disgusted complaint). Far from even keeping a corner in it, he now regards it as a place only fit for toads, Desdemona and her lover knotting in the dark water. To his mind the sublime Desdemona has become 
a thing, a dungeon, a cistern, all of them metaphors for the vagina, caught as he is in a hectic crowd of sexual images.

Othello is lost in his folly. To reach this point, he has had to undergo an utter fragmentation of his conscience. This has happened at the beginning of Act IV. Iago has insisted that he should think: 1.1 "Will you think so?" What should he think of? Iago soon provides him with the object of thinking: he must think of kisses, of Cassio and Desdemona naked in bed but meaning no harm, of what Cassio has disclosed to Iago. What has Cassio said? As usual, Iago works on reticence. "Lie-", he answers. "With her?" Othello plies him. "With her, on her, what you will" is the cruel reply which allows the victim to choose the way in which he prefers to imagine the sexual scene. Othello, of course, knows that Lie has a double meaning - to couch and to tell lies - and tries for a moment to disentangle the sense. But he soon suffers from a hallucination which forbids his discourse to flow any longer and, before swooning, he disintegrates his usually hyperbolic verse into a broken prose:

Lie with her? lie on her? We say lie on her when they belie her! Lie with her, zounds, that's fulsome! - Handcherchief! Confessions! handcherchief! - To confess and be hanged for his labour! First to be hanged, and then to confess: I tremble at it. Nature would not invest herself in such shadowing passion without some instruction. It is not words that shakes me thus. Pish! Noses, ears, and lips. Is't possible? Confess! Handcherchief! O devil! (35-43)

His language is reduced to the fragments of the fabula invented by Iago. The two main proofs which have been produced - the handkerchief and Cassio's alleged confession - are recalled by him without verbs or qualifications: "Handkerchief - confessions handkerchief!" For a moment, in his fury against Cassio, he seems to recollect himself: first he wants him dead, then he argues on the mystery of Nature which cannot go astray with passion unless it receives some instruction. But which passion is he speaking of? Is it his own darkening passion or Desdemona's passion? Possibly both within his distraught mind. But who is the instructor? If it is Desdemona's passion, the instructor should be the perverse nature of women which has resurfaced in her. If it is Othello's passion, the instructor must be somebody who has taught him how to feel such a passion. But he disowns this correct hint: "It is not words that shakes me thus," that is, Iago's words which have worked him up to this point! By this denial - an extreme refusal to acknowledge an external agent for his turmoil - he confirms his passion as the result of his own discovery of the betrayal. And then he loses all trace of self-control: only fragments of bodies, synecdoches of a sexual scene, swirl in his mind: "Pish! Noses, ears, and lips." There is only the time to articulate once again the required revelation of the sin (Confess!) and the "ocular proof" of it (Handkerchief!), and he swoons. Shakespeare's poetry of action reaches here the silence of an inert body. Elocution and inelocution plunge into the abyss where language is denied.

3. I will now turn to the Sonnets, whose poetry, while belonging to the lyrical genre, is still essentially dramatic and circumstantial. The poet always refers to somebody (the fair youth, the dark lady, Time itself in the immortality sonnets, etc.), or addressing himself in interior dialogues. I shall concentrate on the last sonnets of the sequence to the fair friend (numbers 121-125). With the exclusion of sonnet 122, these poems constitute, in my opinion, an interrelated microsequence which adds to the meaning of each one.

Let us start from sonnet 123:

No, Time, thou shalt not boast that I do change!

Thy pyramids built up with newer might 
To me are nothing novel, nothing strange;

They are but dressings of a former sight.

Our dates are brief, and therefore we admire

What thou dost foist upon us that is old,

And rather make them born to our desire

Than think that we before have heard them told.

Thy registers and thee I both defy,

Not wondering at the present nor the past;

For thy records and what we see doth lie,

Made more or less by thy continual haste.

This I do vow, and this shall ever be:

I will be true despite thy scythe and thee.

always been his friend, whose perfect Image had been celebrated as an archetype, living in time but overcoming time, age, and death. In this sonnet, instead, the poet affirms his own immutability in a great challenge to Time, while not aspiring however to immortality: rather, he opposes to the fickleness of Time, to its tricks, shows, and lies, the truth of his unchanging identity. Behind Time it is possible to infer the presence of other addressees: a person (or more than one) who might have put the poet's truth in doubt. In his coherence and honesty, and most of all - as we shall see - in his unselfishness, he strongly refuses any charge of inconsistency and instrumental expediency. False, on the contrary, is Time in its institutional mutability; and false are those who lay traps on the poet.

This interpretation needs to be supported by the context in which the sonnet is placed. Before examining the following two pieces, 124 and 125, it seems convenient to look at sonnet 121 , a poem dealing in general terms with the problem of private morality and the way it is publicly regarded through distortions and malign projections:

'Tis better to be vile than vile esteemed

When not to be receives reproach of being,

And the just pleasure lost, which is so deemed,

Not by our feeling but by others' seeing.

For why should others' false adulterate eyes

Give salutation to my sportive blood?

Or on my frailties why are frailer spies,

Which in their wills count bad what I think good?

No, I am that I am, and they that level

At my abuses reckon up their own.

I may be straight though they themselves be bevel;

By their rank thoughts my deeds must not be shown,

Unless this general evil they maintain

All men are bad and in their badness reign.

The poem starts with an impersonal statement which soon involves a circumstantially personal indignation. The poet rebels against those who obliquely censure his sensual behaviour by looking at him, the 'culprit', with false adulterate eyes: malign persons (spies) who presume to be the keepers of an absolute morality, but, in fact, project their own vices onto the poet. It is the same psychic mechanism which is at work in Iago's projection of his obscene thoughts onto Othello (and Roderigo and Cassio). Faced with the devious attack of such an attitude, the poet asserts his undisputable authenticity with words that reproduce Jahve's declaration to Moses: "I am that I am": an apparently blasphemous assumption which conflicts with the machiavellian one uttered by Iago in the first scene of the tragedy, where he reassures Roderigo that he is going to cheat the 
odious Moor. "In following him, I follow but myself," he says, and then concludes his speech:

For when my outward action does demonstrate

The native act, and figure of my heart,

In complement extern, 'tis not long after,

But I will wear my heart upon my sleeve,

For doves to peck at: I am not what I am. (ll.61-65: my italics) extreme example of Shakespeare's constructive vagueness." ${ }^{18}$ In the context of the microsequence, though, it acquires a much clearer meaning. In this sonnet, too, the poet rebels against a judgement, or better an insinuation, which would bring his patron ("my dear love", l.1) to suspect that his affection is an opportunistic one. Somebody - a spy, as suggested in sonnet 121 , or explicitly the suborned informer we shall meet at the end of the following sonnet - is the false source of such a deception. The milieu, as Booth has noted with reference to sonnet 121, is that of "the ceremony, hypocrisy, backbiting and gossip of courtiers, ${ }^{19}$ and is here signified by a revealing chain of expressions like child of state, smiling pomp, thralled discontent, inviting time, policy. The poet opposes his truth to it by always starting with the absolute negation No, which testifies to his extraordinary assertiveness in all these sonnets - 121, 1.9, "No, I am that I am"; 123, 1.11, "No, Time, thou shalt not boast"; 24,5 , "No, it was builded far from accident"; 125 , 9, "No, let me be obsequious in thy heart." 20

Sonnet 125 concludes the elusive "story":

Were't aught to me I bore the canopy,

With my extern the outward honouring,

Or laid great bases for eternity,

Which proves more short than waste or ruining?

Have I not seen dwellers on form and favour

Lose all and more by paying too much rent,

For compound sweet forgoing simple savour,

Pitiful thrivers in their gazing spent? 
No, let me be obsequious in thy heart,

And take thou my oblation, poor but free,

Which is not mixed with seconds, knows no art

But mutual render, only me for thee.

Hence, thou suborned informer! A true soul

When most impeached stands least in thy control.

43 A link with the previous sonnet has been noted by various critics. ${ }^{21}$ The first two lines take up the theme dealt with at the opening of the previous sonnet: the poet's love is not opportunistic and servile. Were it so, he might undergo a degradation such as the one suffered by "Pitiful thrivers in their gazing spent" (1.5-8) - a destiny analogous to that of sonnet $124,1.2$. But what is most interesting here is the parallelism with Iago's speech in I .i.61-65 quoted above, where he boasts of his ability to simulate and dissimulate his own intentions and his "outward action," so that his "native act," i.e. the "figure" of his heart, will never be revealed in "complement extern." Both outward and extern recur here in the substantive form - and it should be noted that they are the only occurrences in the canon. A peculiar relationship between the tragedy of Othello and this group of sonnets emerges once again, and is confirmed by the striking conclusion of this sonnet which ends the whole sequence devoted to the poet's friend. To him, for the first and only time in this microsequence, the poet finally addresses himself in 1.9-12 asserting that his love knows no other motive than mutual render.

In the couplet the addressee changes all of a sudden with a strong dramatic effect. The spy, the slanderer, up till now only obliquely hinted at in sonnets 121 and 124, appears on the stage, but only to be ousted thence by the true soul of the poet, who is not an Othello ensnared in the deception of a Iago! That deception, though, might have been unintentionally prompted by the suspicion raised in the poet's patron, as suborned seems to imply. What is sure, anyhow, is that, as Kerrigan has observed in a note to sonnet 124, "In this last group of sonnets to the youth [...] writing yields in strength to emotion, verbs of making are given over [...] and sonneteering becomes less sufficient." ${ }^{22}$

Drama comes to the fore. The close of the sequence is perhaps the most striking example of a scenic language in Shakespeare's lyrical poetry. One which is, in most cases, in action, in that it relies on relationships, accidents, events (however elliptically presented they may be), and on the ever-changing moods and frames of mind which mirror a newly relativistic cultural-historical context.

\section{NOTES}

1. The quotation is drawn from The Romantics on Shakespeare, ed. Jonathan Bate, Harmondsworth, Penguin Books, 1992, 162-63; the reference is to Specimens of the Table Talk of Samuel Taylor Coleridge, 2 vols, ed. H. N. Coleridge ( $2^{\text {nd }}$ ed., London, 1836), 7 April 1833 and 5 March 1834.

2. Still in regard to Shakespeare's language, he writes on another occasion: “...in many instances, the predominance of some mighty Passion takes the place of the guiding Thought, and the result presents the method of Nature, rather than the habit of the Individual. For Thought, Imagination (and we may add, Passion), are, in their very essence, the first, connective, the latter co- 
adunative" (Jonathan Bate, op. cit., p. 158, which refers to Essays on the Principles of Method, Section the Second, Essay iv of The Friend: A Series of Essays in Three Volumes, London, 1818). While thought has the function of connecting, imagination and passion have "the attribute of combining in one" (according to the definition of coadunative - a neologism in the lexicon - given by The Oxford English Dictionary). See also the adverb coadunatively, "By way of coadunation" (OED), which occurs in Literary Remains (1839), IV.197: "The philosophic principle that can only act immediately, that is, interpenetratively, as two globules of quicksilver, and co-adunatively..." By inventing these new words Coleridge wants to convey his idealistic concept of the creative, or philosophical, discourse as that which transmits the linearity of thought through the simultaneity of passion and imagination.

3. Frank Kermode, Shakespeare's Language, New York, Allen Lane, The Penguin Press, 2000, 16.

4. Ibidem, 16-17. Kermode is here referring in particular to Aufidius' monologue in Coriolanus, IV .7.28-53.

5. Keir Elam, “'Thou art mad to say it'. Seven types of Ineffability in 'Macbeth”, Semeia, Bologna, Il Mulino, 1994, 203.

6. Nigel Alexander, ed., William Shakespeare, Hamlet, Houndmills Basingstoke, Hampshire and London, Macmillan Education, 1976, 68.

7. As Frank Kermode puts it, "If only time could be made to stop at the desired moment of the future! However, to be and to end are antithetical, they can only contradict each other [...] The act of murder cannot be an end; nothing in time can, in that sense, be 'done"' (Op. cit., 208-9).

8. I will not comment on these lines further, since I have already presented my interpretation in "Translating Shakespeare: a Brief Survey of some Problematic Areas", Translating Shakespeare in the Twenty-First Century, ed. Rui Carvalho Homem and Ton Hoenselaars, Rodopi, Amsterdam, New York, 2004, 38-41.

9. As Nicholas Brooke has noted in his edition of the play, Oxford, New York, O.U.P., 1994, 118.

10. William Empson, Seven Types of Ambiguity, ( $3^{\text {rd }}$ ed.), Norfolk, New Direction Book, 1953, 50.

11. In his edition of the play, Oxford, New York, O.U.P., 1996, 102.

12. In The Norton Shakespeare, Stephen Greenblatt, General Ed., New York and London, 1997.

13. "Bellaria, who in her time was the flower of courtesy, willing to shew how unfeignedly she loved her husband by his friend's entertainment, used him likewise so familiarly that her countenance bewrayed how her mind was affected towards him, oftentimes coming herself in his bed chamber to see that nothing should be amiss to mislike him. This honest familiarity increased daily more and more betwixt them [...] there grew such a secret uniting of their affections, that the one could not well be without the company of the other [...] He [PandostoLeontes] then began to measure all their actions, and [to] misconstrue of their private familiarity, judging that it was not for honest affection, but for disordinate fancy, so as he began to watch them more narrowly..." (my italics).

14. I have given a more detailed analysis of this scene in an essay, "Translation and Performance", in Shifting the Scene. Shakespeare in European Culture, Ladina Bezzola Lambert and Balz Engler (eds), University of Delaware Press, Newark, 2004, 275-79.

15. Starting from this point of the play, Patricia Parker notes a concentration of language on "the 'privities' of woman" ("Fantasies of 'Race' and 'Gender': Africa, Othello, and Bringing to Light", in Hendricks and Parker (eds), Women, "Race", and Writing in the Early Modern Period, NewYork and London, Routledge, 1993, 87). For a diffuse playful exploitation of the theme of the vagina's bounteousness see the Will sonnets, 135 and 136.

16. For a similar use of cistern as the place of uncontrolled lust see Malcolm's speech in Macbeth, IV.iii.60-63: "But there's no bottom, none, / In my voluptuousness. Your wives, your daughters, / Your matrons, and your maids, could not fill up / The cistern of my lust..."; and Cleopatra's speech in Antony and Cleopatra, II.v.93-5: "O, I would thou didst, / So half my Egypt were submerged and made / A cistern for scaled snakes." 
17. John Kerrigan (ed.), The Sonnets and A Lover's Complaint, Harmondsworth, Penguin Books, $1986,342$.

18. Stephen Booth, Shakespeare's Sonnets, New Haven and London, Yale University Press, 1977, 419.

19. Op. cit., 409.

20. No occurs only six times in the canon, four of which are found in this group of sonnets.

21. See John Kerrigan for instance: "The poet responds to the criticism of an onlooker (perhaps one of those described in Sonnet 121) who has apparently suggested that his love is just the child of state (124.1), by insisting that he recognizes the vanity of pomp and circumstance and has been impressed in the past by the folly of those seduced by appearances" (Op. cit., 348).

22. Op. cit., p. 346.

\section{ABSTRACTS}

Drawing from my experience as a critic-translator, I will investigate some of Shakespeare's distinctive ways of creating poetry in action: that is, at the same time, poetry developing in a staged context and therefore endowed with a performative power, and poetry growing out of a dialectics between passion and thought. Whether the text is a play or a narrative poem, or a sonnet - though in the latter cases through different modes of expression -, Shakespeare's poetry always conveys the process of minds in situation.

Puisant dans mon expérience de critique-traducteur, je m'attacherai à sonder certaines façons caractéristiques dont Shakespeare crée la poésie en action : à savoir, à la fois, la poésie qui se construit dans un contexte de mise en scène et par conséquent dotée d'une puissance performative, et la poésie qui est le fruit d'une dialectique entre passion et pensée. Que le texte soit une pièce ou un poème narratif, ou encore un sonnet (bien que dans ces derniers cas les modes d'expression soient différents), la poésie de Shakespeare véhicule toujours le processus d'esprits en situation.

\section{AUTHOR}

\section{ALESSANDRO SERPIERI}

Alessandro Serpieri is Professor Emeritus of English Literature at the University of Florence. His main fields of interest are : theory of drama, literature and psychoanalysis, translation studies, romantic and modern poetry, Donne, Eliot, Conrad, Beckett, and, most of all, Shakespeare. Among his main publications : John Webster (1965), Shakespeare : I sonetti dell'immortalità (1975), Otello : l'Eros negato, (1978, revised edition 2003), Retorica e immaginario (1986), Nel laboratorio di Shakespeare : dalle fonti ai drammi (éd., 4 vol., 1988), On the Language of Drama (1989), Polifonia shakespeariana (2002). 